\title{
PENINGKATAN KOMPETENSI GURU TK ABA 16 MALANG DALAM PENGUASAAN MEDIA PEMBELAJARAN ONLINE DI MASA PANDEMI COVID-19
}

\author{
Merinda Lestandy ${ }^{1}$, Nurhadi ${ }^{2}$, Abdurrahim ${ }^{3}$, Muhammad Bara Al Farisyi ${ }^{4}$ \\ ${ }^{1)}$ Program Studi D3 Teknologi Elektronika, Fakultas Teknik, Universitas Muhamaddiyah Malang \\ ${ }^{2)}$ Program Studi Teknik Elektro, Fakultas Teknik, Universitas Muhamaddiyah Malang \\ ${ }^{3,4)}$ Mahasiswa, Program Studi Teknik Elektro, Fakultas Teknik, Universitas Muhamaddiyah Malang \\ e-mail: merindalestandy@umm.ac.id
}

\begin{abstract}
Abstrak
Penyebaran pandemi virus COVID-19 telah memberikan tantangan tersendiri bagi lembaga pendidikan di Indonesia. Akibatnya membuat sektor pendidikan seperti sekolah menghentikan proses pembelajaran secara tatap muka. Sebagai gantinya, proses pembelajaran dilaksanakan secara daring (online) yang bisa dilaksanakan dari rumah masing-masing murid. Perpindahan sistem belajar konvensional ke sistem daring amat mendadak dan tanpa persiapan matang. Tetapi semua ini harus tetap dilaksanakan agar proses pembelajaran dapat berjalan lancar dan murid aktif mengikuti walaupun dalam kondisi pandemic COVID-19. Kesiapan dari pihak sekolah maupun murid merupakan tuntutan dari pelaksanaan daring. Pelaksanaan daring ini memerlukan perangkat pendukung seperti komputer dan media pembelajaran online yang terhubung dengan internet. Penggunaan beberapa aplikasi pada pembelajaran daring sangat membantu guru dalam proses pembelajaran saat di masa pandemic. Perlu disadari bahwa ketidaksiapan guru dan siswa terhadap pembelajaran daring juga menjadi masalah. Selain itu permasalahan lain yang dimiliki sekolah yaitu mengenai bahan ajar yang hanya sekedar perintah berupa lisan sehingga membuat muridsiswi TK merasa bosan. Hal tersebut dikarenakan para guru belum memanfaatkan fasilitas Teknologi Informasi dan Komunikasi (TIK) yang ada untuk media pembelajaran online secara optimal. Selain itu, para guru juga belum memiliki kompetensi untuk mengembangkan bahan pembelajaran berbasis TIK selama pembelajaran online. Maka dari itu, kegiatan pengabdian ini mengusulkan workshop dan pendampingan untuk meningkatkan kompetensi guru TK Aisyisyah Busthanul Athfal (ABA) 16 Malang dalam menggunakan media pembelajaran online di masa pandemic ini.
\end{abstract}

Kata kunci: COVID-19; Media Pembelajaran Online; Kompetensi Guru

\begin{abstract}
The spread of the COVID-19 virus pandemic has presented its own challenges for educational institutions in Indonesia. As a result, the education sector, such as schools, stop the face-to-face learning process. Instead, the learning process is carried out online which can be carried out from each student's home. The transfer of conventional learning systems to online systems was sudden and without proper preparation. But all of this must be carried out so that the learning process can run smoothly and students actively follow even in the COVID-19 pandemic. Readiness on the part of schools and students is a demand for online implementation. This online implementation requires supporting devices such as computers and online learning media that are connected to the internet. The use of several applications in online learning is very helpful for teachers in the learning process during a pandemic. It should be realized that the unpreparedness of teachers and students towards online learning is also a problem. Apart from that, another problem that schools have is regarding teaching materials which are only verbal commands, so that kindergarten students feel bored. This is because the teachers have not utilized the existing Information and Communication Technology (ICT) facilities for online learning media optimally. In addition, teachers also do not have the competence to develop ICT-based learning materials during online learning. Therefore, this service activity proposes workshops and mentoring to improve the competence of TK Aisyisyah Busthanul Athfal (ABA) 16 Malang teachers in using online learning media during this pandemic.
\end{abstract}

Keywords: COVID-19; Online Learning Media; Teacher Competence 


\section{PENDAHULUAN}

Penyebaran pandemi virus COVID-19 telah memberikan tantangan tersendiri bagi lembaga pendidikan di Indonesia. Demi mengantisipasi penularan virus tersebut pemerintah mengeluarkan kebiajakn seperti social distancing, physical distancing, hingga Pembatasan Sosial Berskala Besar (PSBB). Kondisi ini mengharuskan masyarakat untuk tetap diam di rumah, belajar, bekerja dan beribadah di rumah. Akibat dari kebijakan tersebut membuat sektor pendidikan seperti sekolah menghentikan proses pembelajaran secara tatap muka. Sebagai gantinya, proses pembelajaran dilaksanakan secara daring (online) yang bisa dilaksanakan dari rumah masing-masing murid.

Pembelajaran daring bertujuan memberikan layanan pembelajaran bermutu secara dalam jaringan (daring) yang bersifat massif dan terbuka untuk menjangkau audiens yang lebih banyak dan lebih luas (Maudiarti, 2018). Perlu disadari bahwa ketidaksiapan guru dan murid terhadap pembelajaran daring juga menjadi masalah(Wicaksono, 2012). Perpindahan sistem belajar konvensional ke sistem daring amat mendadak dan tanpa persiapan matang. Tetapi semua ini harus tetap dilaksanakan agar proses pembelajaran dapat berjalan lancar dan murid aktif mengikuti walaupun dalam kondisi pandemic COVID-19. Penggunaan beberapa aplikasi pada pembelajaran daring sangat membantu guru dalam proses pembelajaran saat di masa pandemic(Arnesti \& Hamid, 2015).

Sesuai dengan Surat Edaran Mendikbud Nomor 4 Tahun 2020 Tentang Pelaksanaan Kebijakan Pendidikan dalam Masa Darurat Penyebaran Corona Virus Disease (COVID-19) menganjurkan untuk melaksanakan proses belajar dari rumah melalui pembelajaran daring(Azhar et al., 2020). Kesiapan dari pihak sekolah maupun murid merupakan tuntutan dari pelaksanaan daring. Pelaksanaan daring ini memerlukan perangkat pendukung seperti komputer dan media pembelajaran online yang terhubung dengan internet.

Guru harus memastikan kegiatan belajar mengajar tetap berjalan dan saling berinteraksi, meskipun murid berada dirumah. Solusinya, guru dituntut dapat mendesain media pembelajaran sebagai inovasi dengan memanfaatkan media daring (online) (Maryani et al., 2018). Hal ini sesuai dengan Menteri Pendidikan dan Kebudayaan Republik Indonesia terkait Surat Edaran Nomor 4 Tahun 2020 tentang Pelaksanaan Kebijakan pendidikan dalam Masa Darurat Penyebaran Corona Virus Disease (COVID-19). Guru merupakan unsur dominan dalam proses pendidikan, sehingga kualitas pendidikan banyak ditentukan oleh kualitas pendidik dalam menjalankan peran dan tugasnya di masyarakat(Kunci \& Guru, 2007). Kompetensi guru merupakan penguasaan kemampuan yang harus dimiliki guru agar mewujudkan kinerjanya secara tepat dan efektif disekolah, salah satunya pada Taman Kanak-kanak (TK).

TK merupakan salah satu bentuk pendidikan pra sekolah yang menyediakan program pendidikan dini bagi anak usia dini (usia empat tahun sampai memasuki pendidikan dasar). Menurut Peraturan Daerah Nomor 27 tahun 1990, tentang Pendidikan Prasekolah Bab 1 Pasal 1 ayat (2) Pendidikan di TK dilaksananakan dengan prinsip bermain sambal belajar atau belajar seraya bermain sesuai dengan perkembangan anak didik. Adapun tujuan TK berdasarkan keputusan Menteri Pendidikan dan Kebudayaan Nomor 0486/U/92 tentang TK adalah membantu meletakkan dasar kearah perkembangan sikap pengetahuan, ketrampilan dan daya cipta yang diperlukan oleh anak pertumbuhan serta perkembangan selanjutnya. Berdasarkan uraian tersebut, tim pelaksana memberikan pengabdian di TK Aisyiayah Bustanul Athfal (ABA) 16 Malang untuk menanggulani proses pembelajaran daring selama pandemi ini. 


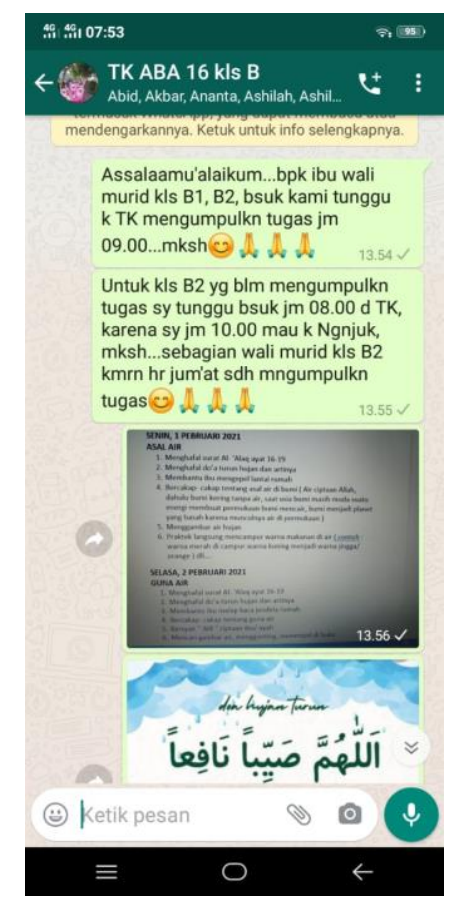

Gambar 1. Group WAG Wali Murid

Berdasarkan hasil survey dan wawancara yang telah dilakukan tim pelaksana dengan pihak sekolah, terungkap persoalan-persoalan yang sedang dihadapi sehubungan dengan pelaksanaan pembelajaran secara daring (online). Selama daring, TK ABA 16 Malang memanfaatkan fasilitas WhatsApp Group (WAG) yang didalamnya berisi wali murid murid. Pada Gambar 1. dibawah ini dapat dilihat bahwa setiap harinya guru mengirimkan bahan ajar dan tugas melalui WAG untuk dikerjakan murid. Pengumpulan tugas juga dilakukan secara kolektif sesuai dengan jadwal pengumpulan yang diberikan oleh guru kemudian wali murid murid mengirimkan tugas tersebut melalui WAG. Sehingga, hal tersebut menyebabkan menumpuknya data pada memori handphone para guru. Selain itu, selama pembelajaran online para guru juga dituntut untuk dapat mendokumentasikan proses pembejaran minimal tugas-tugas yang telah dikerjakan oleh murid. Akan tetapi, fasilitas yang sudah tersedia tersebut belum diikuti dengan tersedianya media pembelajaran interaktif dan bahan pembelajaran yang menarik bagi murid TK.

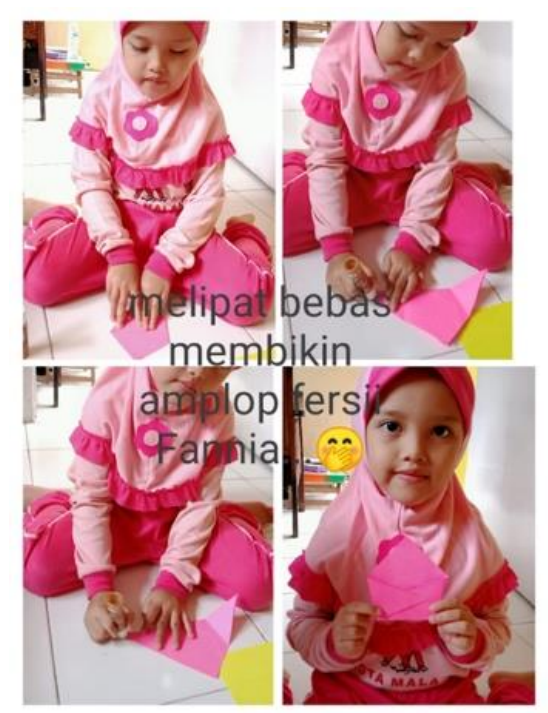

Gambar 2. Contoh Pengumpulan Tugas Murid 
Pada Gambar 2. Diatas dapat merupakan salah satu contoh pengumpulan tugas murid yang dikirimkan oleh wali murid melalui WAG. Setelah mendapatkan tugas yang diberikan oleh guru, maka murid akan mengerjakan sesuai dengan perintah yang diberikan dengan arahan wali murid. Apabila perintah yang diberikan para guru hanya sekedar lisan dan kurang menarik maka murid akan merasa bosan. Hal ini disebabkan, ketika di sekolah murid menerima bahan ajar secara menarik dan visual sedangkan selama online hanya mendapatkan perintah secara lisan.

Para guru juga menyadari bahwa bahan ajar yang diberikan untuk murid-siswi TK ABA 16 Malang selama daring juga kurang menarik. Bahan ajar tersebut hanya sekedar perintah berupa lisan sehingga membuat murid-siswi TK merasa bosan seperti yang terlihat pada Gambar 1. Hal tersebut dikarenakan para guru belum memanfaatkan fasilitas Teknologi Informasi dan Komunikasi (TIK) yang ada untuk media pembelajaran online secara optimal. Selain itu, para guru juga belum memiliki kompetensi untuk mengembangkan bahan pembelajaran berbasis TIK selama pembelajaran online.

\section{METODE}

Pencapaian tujuan yang telah ditetapkan dalam kegiatan ini dilaksanakan dengan beberapa metide sebagai berikut :

1. Metode ceramah : metode ini digunakan untuk menyampaikan teori, konsep dan prinsip yang sangat penting untuk dimengerti dan dikuasi oleh para guru TK ABA 16 Malang.

2. Metode demonstrasi : metode ini menunjukkan dan memperagakan proses kerja yang sistematis, mudah dikerjakan dan diikuti oleh para guru.

3. Metode praktek/latihan : metode ini digunakan untuk memberikan tugas kepada para guru untuk mempraktekkan secara langsung mengenai pembuatan media pembelajaran online yang telah disampaikan.

Berdasarkan hal tersebut, maka disusunlah alur pelatihan dalam bagan kerangka berpikir dapat dilihat pada Gambar 3.

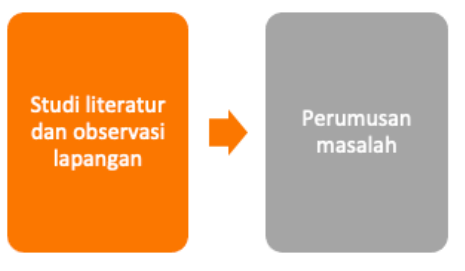

\section{Rencana Kegiatan}

- Bulan pertama : tim pengusul mendiskusikan program pengabdian dengan mitra.

- Bulan kedua : survey dan wawancara dengan pihak mitra mengenai persoalan-persoalan yang sedang dihadapi sehubungan dengan pelaksanaan pembelajaran secara daring (online).

- Bulan ketiga : workshop dan pendampingan pembuatan materi/bahan ajar dengan menggukan power point dengan menarik.

- Bulan keempat : workshop dan pendampingan dengan mengubah dari cara manual menjadi lebih terstruktur dengan memaksimalkan media pembelajaran online (Google Classroom).

- Bulan kelima : Monitoring dan evaluasi, pendampingan dan penilaian atas capaian yang telah dilaksanakan antara tim pengusul dengan mitra.

Partisipasi Mitra dalam pelaksanaan kegiatan pengabdian

- Mitra : menyediakan bahan, tempat dan sumber daya manusia yang siap dilatih dan bersedia monitoring dan evaluasi, pendampingan dan penilaian atas capaian program yang telah dilaksanakan antara tim pengusul dengan mitra.

- Tim pengusul : memfasilitasi dan mendampingi serta membina mitra dari mulai awal hingga akhir progam. 


\section{Monitoring dan evaluasi}

- Monitoring : setelah workshop dan pendampingan akan dimonitoring semua kegiatan yang sudah berjalan apakah sesuai dengan program yang telah disepakati oleh semua pihak.

- Evaluasi : evaluasi dilakukan guna mengetahui seberapa besar tingkat keberhasilan kegiatan pengabdian ini mampu mengubah kondisi mitra sesuai dengan persoalan yang ada pada mitra.

\section{HASIL DAN PEMBAHASAN}

Tim pengusul melakukan survey awal untuk mengetahui persoalan-persoalan yang sedang dihadapi sehubungan dengan pelaksanaan pembelajaran secara daring (online). Permasalahan yang dihadapi mitra diantaranya belum adanya model dan strategi pembelajaran daring yang digunakan para guru karena masih menggunakan metode konvensional yaitu dengan mengirimkan soal lisan ke dalam grup WA wali murid. Selain itu, permasalahan yang lain yaitu belum adanya media pembelajaran daring yang digunakan sekolah untuk mempermudah proses pembelajaran agar lebih efisien dan terstruktur. Hal ini disebabkan pada selama daring, TK ABA 16 Malang hanya memanfaatkan fasilitas WhatsApp Group (WAG) yang didalamnya berisi wali murid murid. Solusi dari permasalahan-permasalahan tersebut yaitu tim pengusul akan melaksanakan workshop dan pendampingan pembuatan bahan ajar pembelajaran online serta melaksanakan pelatihan pembelajaran online dengan menggunakan Google Classroom di masa pandemi ini. Setelah melaksanakan pelatihan, tim pengusul akan memonitoring dan mengevaluasi penggunaan media pembelajaran yang sudah diimplementasikan oleh mitra. Output dari kegiatan pengabdian ini diantaranya dapat meningkatkan ketrampilan dan kemampuan guru dalam pembuatan bahan ajar dan menggunaan media pembelajaran online sehingga dapat meningkatkan kompetensi guru TK ABA 16 Malang. Gambaran ipteks kegiatan pengabdian dapat dilihat pada Gambar 4.

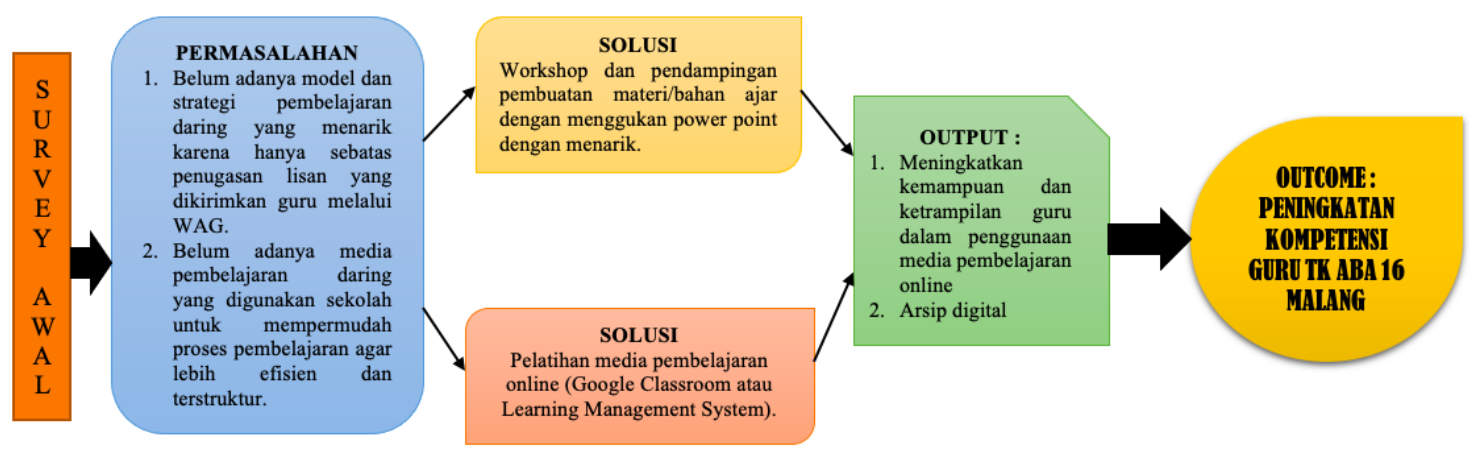

Gambar 4. Gambaran Ipteks

Workshop dimulai dengan mengenalkan terlebih dahulu mengenai pentingnya teknologi informasi bagi pendidikan terutama di saat pandemi. Kemudian para guru diberikan pelatihan mengenai bagaimana membuat materi pembelajaran dengan memanfaatkan powerpoint dengan menggunakan internet. Karena selama ini para guru menggunakan metode konvensional yaitu dengan cara menuliskan tanpa adanya gambar yang menarik sehingga para murid merasa bosan. Pada Gambar 5. dibawah ini adalah contoh hasil materi yang dibuat dengan menggunakan powerpoint. 


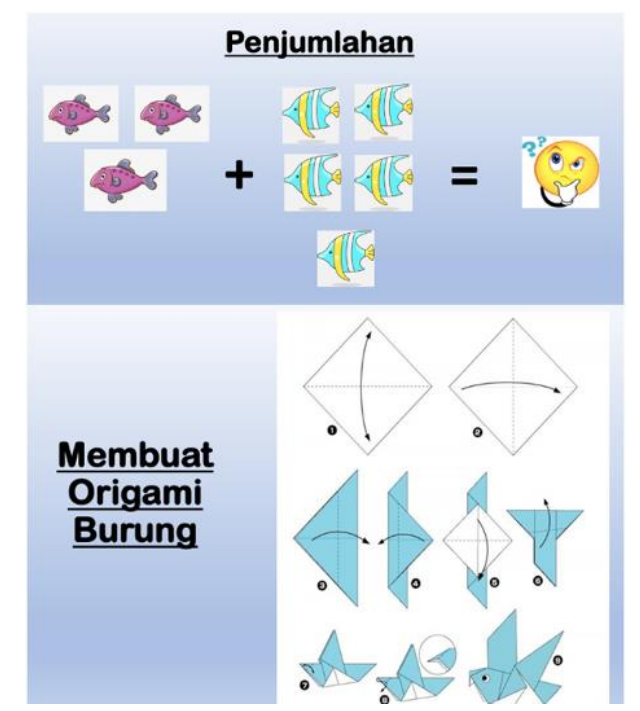

Gambar 5. Materi Belajar dengan Menggunakan Powerpoint
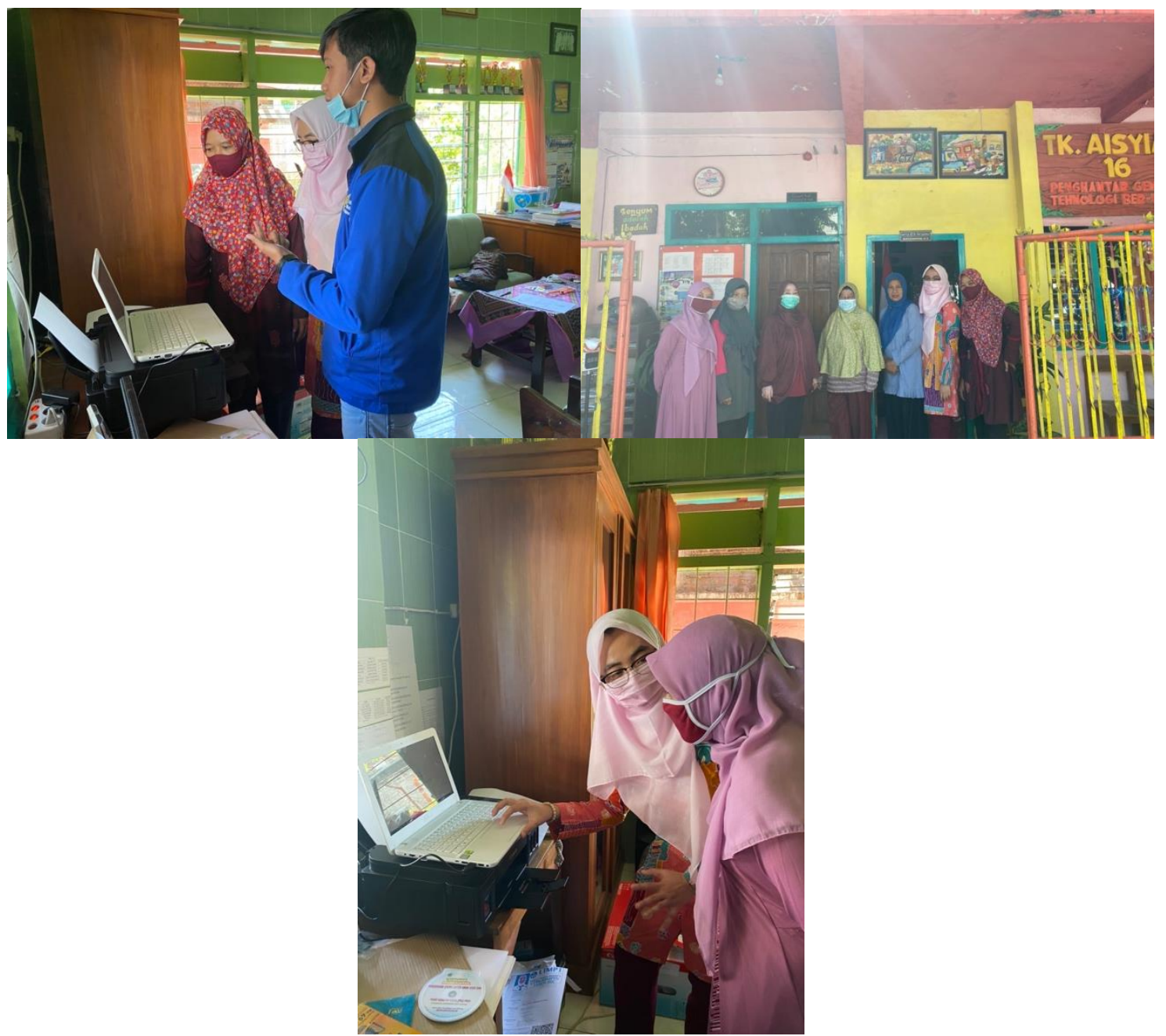

Gambar 6. Dokumentasi Workshop

\section{SIMPULAN}

Berdasarkan pengabdian ini, peneliti melihat adanya potensi bagi guru TK ABA 16 Malang bagi perkembangan pendidikan di masa pandemi dimana semua dituntut untuk memahami teknologi informasi. Serangkaian workshop yang dilaksanakan dalam kegiatan pengabdian ini menunjukkan bahwa para guru memiliki kompetensi untuk mengembangkan sekolah dengan memanfaatkan teknologi informasi. 


\section{SARAN}

Berdasarkan hasil kesimpulan diatas maka saran yang dapat diberikan yaitu bagi guru TK ABA 16 Malang agar kiranya lebih memperhatikan dan memanfaatkan teknologi informasi yang sudah ada dengan mengasah serta terus mengembangkan diri.

\section{UCAPAN TERIMA KASIH}

Terimakasih kepada Direktorat Penelitian dan Pengabdian Kepada Masyarakat (DPPM) Universitas Muhammadiyah Malang atas dukungan terselenggaranya pekerjaan ini melalui skema Program Pengabdian Masyarakat Internal (PPMI) 2021.

\section{DAFTAR PUSTAKA}

Arnesti, N., \& Hamid, A. (2015). Penggunaan Media Pembelajaran Online - Offline Dan Komunikasi Interpersonal Terhadap Hasil Belajar Bahasa Inggris. Jurnal Teknologi Informasi \& Komunikasi Dalam Pendidikan, 2(1). https://doi.org/10.24114/jtikp.v2i1.3284

Azhar, E. I., Hui, D. S. C., Memish, Z. A., Drosten, C., Zumla, A., \& Kemdikbud RI. (2020). Edaran Tentang Pencegahan Wabah COVID-19 di Lingkungan Satuan Pendidikan Seluruh Indonesia. Infect Dis Clin North Am, 33, 1-5.

Kunci, K., \& Guru, P. (2007). Upaya Pengembangan Profesionalisme Guru Di Indonesia. Jurnal Ekonomi \& Pendidikan, 4(1), 76-88. https://media.neliti.com/media/publications/17245-IDupaya-pengembangan-profesionalisme-guru-di-indonesia.pdf

Maryani, I., Mustofa, A., \& Septian Emma Dwi, J. (2018). Efektivitas Pendampingan Kelompok Dalam Meningkatkan Motivasi Berwirausaha Peternak Sapi Perah. JPPM (Jurnal $\begin{array}{lllll}\text { Pengabdian Dan } & \text { Pemberdayaan }\end{array}$ https://doi.org/10.30595/jppm.v2i1.2059

Maudiarti, S. (2018). PENERAPAN E-LEARNING DI PERGURUAN TINGGI Santi Maudiarti Sekolah Tinggi Pariwisata Trisakti. PERSPEKTIF Ilmu Pendidikan, 32(1), 53-68.

Wicaksono, S. R. (2012). Kajian Pembelajaran Online Berbasis Wiki Di Lingkup Perguruan Tinggi. Journal of Education and Learning (EduLearn), 6(1), 51. https://doi.org/10.11591/edulearn.v6i1.190 